\title{
Morphological characterization of pollens from three Apiaceae species and their ingestion by twelve-spotted lady beetle (Coleoptera: Coccinellidae)
}

\author{
V. A. D'Ávila *, E. L. Aguiar-Menezes ${ }^{b}$, V. Gonçalves-Esteves ${ }^{c}$, C. B. F. Mendonça ${ }^{c}$, R. N. \\ Pereira $^{d}$ and T. M. Santos ${ }^{b}$
}

aPrograma de Pós-graduação em Fitossanidade e Biotecnologia Aplicada, Universidade Federal Rural do

Rio de Janeiro - UFRRJ, Rodovia BR 465, Km 7, CEP 23897-000, Seropédica, RJ, Brazil

${ }^{\text {b}}$ Departamento de Entomologia e Fitopatologia, Universidade Federal Rural do Rio de Janeiro - UFRRJ, Rodovia BR 465, Km 7, CEP 23897-000, Seropédica, RJ, Brazil

'Departamento de Botânica, Museu Nacional, Universidade Federal do Rio de Janeiro - UFRJ, Quinta da Boa Vista, São Cristóvão, CEP 20940-040, Rio de Janeiro, RJ, Brazil

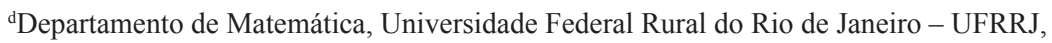
Rodovia BR 465, Km 7, CEP 23897-000, Seropédica, RJ, Brazil

*e-mail: viniciusabreu2@hotmail.com

Received: May 10, 2015 - Accepted: June 29, 2015 - Distributed: August 31, 2016

(With 1 figure)

\begin{abstract}
Larvae and adults of certain species of predator lady beetles feed on pollen, guaranteeing their survival, and at times, reproduction in the absence of preferred prey. Palynology, therefore, may contribute in the investigation of botanical families visited by these predators in order to obtain this floral resource. There are records of the visitation of Apiaceae flowers by Coleomegilla maculata DeGeer, 1775 (Coleoptera, Coccinellidae), but not the ingestion of their pollen grains by this lady beetle. The external morphology of pollen grains of three Apiaceae aromatic species (Anethum graveolens L., Coriandrum sativum L., Foeniculum vulgare Mill.) was characterized, and it was evaluated the ingestion of these pollens by fourth instar larvae and adults of C. maculata upon confinement along with flowers of these Apiaceae for 24 and 48 hours. The pollen grains of those species presented similar external morphology. In the two times of exposure, the larvae ingested the same amount of pollen from the three Apiaceae species, and the amount of $C$. sativum pollen ingested was the same between larvae and adults. The amount of $A$. graveolens pollen grains ingested by the adults was significantly greater than the pollens of $C$. sativum and F. vulgare, in 24 hours, with the opposite occurring in 48 hours. In the first 24 hours, the adults ingested more $A$. graveolens pollen than the larvae, with the opposite occurring with F. vulgare. There was no significant difference in the amount of Apiaceae pollen ingested between larvae and adults in 48 hours. The results suggest that the pollen-eating habits of certain aphidophagous lady beetles may be crucial in their preservation within agro-ecosystems.
\end{abstract}

Keywords: aphidophagous lady beetle, pollinivory, aromatic plant, conservation biological control.

\section{Caracterização morfológica de três espécies de Apiaceae e sua ingestão pela joaninha de doze pintas (Coleoptera: Coccinellidae)}

\begin{abstract}
Resumo
Larvas e adultos de certas espécies de joaninhas predadoras podem se alimentar de pólen, garantindo a sua sobrevivência, e, às vezes, a reprodução na ausência da presa preferencial. Palinologia, portanto, pode contribuir na investigação de famílias botânicas visitadas por estes predadores a fim de obter esse recurso floral. Há registros da visitação de flores de Apiaceae por Coleomegilla maculata DeGeer, 1775 (Coleoptera, Coccinellidae), mas não da ingestão de seus grãos de pólen por essa joaninha. A morfologia externa de grãos de pólen de três espécies aromáticas de Apiaceae (Anethum graveolens L., Coriandrum sativum L., Foeniculum vulgare Mill.) foi caracterizada e avaliou-se a ingestão desses polens por larvas de quarto instar e adultos de $C$. maculata em confinamento com flores dessas Apiaceae por 24 e 48 horas. Os grãos de pólen dessas espécies apresentaram morfologia externa semelhante. Nos dois tempos de exposição, as larvas ingeriram a mesma quantidade de pólen das três espécies de Apiaceae, e a quantidade de pólen de C. sativum ingerida foi semelhante entre as larvas e adultos. A quantidade de grãos de pólen de A. graveolens ingerida pelos adultos foi significativamente maior do que a dos polens de $C$. sativum e $F$. vulgare, em 24 horas, com o oposto
\end{abstract}


ocorrendo em 48 horas. Nas primeiras 24 horas, os adultos ingeriram mais pólen de $A$. graveolens do que as larvas, ocorrendo o oposto com $F$. vulgare. Não houve diferença significativa na quantidade de pólen de Apiaceae ingerida entre as larvas e adultos em 48 horas. Os resultados sugerem que o hábito de alimentar de pólen de certas joaninhas afidófagas pode ser crucial para a sua preservação dentro dos agroecossistemas.

Palavras-chave: joaninhas afidófagas, polinivoria, planta aromática, controle biológico conservativo.

\section{Introduction}

Predator Coccinelidae (Coleoptera) are normally found in different crops, where they contribute to the natural biological control of pest-insects, and are considered efficient biological control agents due to being voracious feeders, having a large ability to find prey as well as a generalist feeding habit, occupying all of the preys' habitats and being predators in the larval and in the adult phases (Hodek and Honek, 1996; Obrycki and Kring, 1998; Almeida and Ribeiro-Costa, 2009).

Coleomegilla maculata has a polyphagous feeding habits and is normally present in agro-ecosystems, including Brazil, where it develops and reproduces itself well when feeding on aphids alone, or even on eggs and neonate larvae of Lepidoptera and Coleoptera (Patt et al., 1997a; Harmon et al., 2000; Lundgren et al., 2005; Lixa et al., 2010).

However, pollen may comprise up to $50 \%$ of its diet (Hoffmann and Fordsham, 1993). The ingestion of corn pollen grains (Zea mays L., Poaceae) by larvae and adult C. maculata has been recorded, and whose mean average protein content was estimated at $24 \%$ (Roulston et al., 2000), making up quite an attractive botanical species for this coccinellid (Smith, 1965; Lundgren et al., 2005; Weber and Lundgren, 2011). Hippodamia convergens Guérin-Méneville, 1842 (Coleoptera: Coccinelidae) adults collected in organic vegetable crops were also determined as being able to ingest pollen grains from ten botanical families, including Apiaceae, although their species were not identified (Medeiros et al., 2010).

Thus, offering attractive flowers to these predator insects represents an agricultural practice to be considered regarding the preservation of said insects in and around the agro-ecosystems, since the nectar (source of carbohydrates) and/or pollen (source of proteins) of these flowers constitute nourishment that could prolong the longevity and fertility of certain predator insects, and consequently, becomes a requirement to optimize their efficacy as biological control agents of agricultural pests (Clercq et al., 2005; Barbosa et al., 2011).

Nevertheless, many botanical species have a floral morphology that may facilitate, deter or prevent the access of anthophilous insects to flower resources, especially nectar and pollen. In this way, the accessibility of entomophagous insects to these resources composes a primary factor in choosing the vegetable species that could be used to make up the crop system and optimize natural biological control (Patt et al., 1997b; Vattala et al., 2006; Barbosa et al., 2011).

In this aspect, entomopalynology, studying the morphology of pollen grains associated with insects (Jones and Jones, 2001), becomes an important tool to aid the development of conservative biological control, for it can permit the identification of pollen ingested by adults, and sometimes, the larvae of predator insects. However, the palynological studies applied to these biological control agents are still scarce, mainly when compared to pollinator insects, such as the melliferous bees (Jones and Jones, 2001; Medeiros et al., 2010).

There are no reports in the literature on the ingestion of Apiaceae pollen grains by C. maculata, although it is known that their species, such as Anethum graveolens L., Coriandrum sativum L., Foeniculum vulgare Mill. are among the plants that attract the aphidophagous lady beetles, including C. maculata, that visit them frequently during the flowering phase, most likely in search of their flower resources, such as pollen (Patt et al., 1997a, b; Ambrosino et al., 2006; Lixa et al., 2010; Resende et al., 2011).

Therefore, the objective of this work was to characterize the morphology of the pollen grains from three species of the Apiaceae family, evaluate the pollen ingestion capacity by fourth instar larvae and adults of $C$. maculata, and if ingested, verify whether there was a difference in the quantity of these pollens between these two development phases of the insect.

\section{Material and Methods}

\subsection{Morphological characterization of the pollens}

The selected Apiaceae species were the following: A. graveolens (dill), C. sativum (coriander) e F. vulgare (fennel), as they are considered aromatic plants. The seedlings of these species were created in polystyrene trays from the seeds, kept in greenhouse of the Departamento de Entomologia e Fitopatologia (DEnF) at the Universidade Federal Rural do Rio de Janeiro- UFRRJ (Seropédica, RJ, Brazil). Upon completing 30 days (June 13, 2011), the seedlings were transplanted to flowerbeds sized $1.2 \times 2.4 \mathrm{~m}$ located in the DEnF experimental area. A spacing of $0.3 \mathrm{~m}$ was used between rows and the plants, giving a total of 32 plants per flowerbed. The fertilization consisted of $2 \mathrm{~kg}$ of composted cattle manure per square meter of flowerbed. The coriander, dill and fennel plants began blossoming on August 20, 2011, September 1, 2011 and September 26,2011 , respectively.

Pre-anthesis buds of the three Apiaceae species were collected and transported in glass vials with $70 \%$ alcohol to the Palynology Laboratory belongs to the Botanical Department of the National Museum at the Universidade Federal do Rio de Janeiro-UFRJ (Rio de Janeiro, RJ, Brazil), where they were submitted to the acetolysis method with 
modified proposals (Erdtman, 1960; Melhem et al., 2003), for the morphological characterization of the pollen grains and reference slide assembly for each botanical species. The microscopic slide preparation was conducted with glycerin gelatin, according to Kisser (1935). The pollen grain characterization was based on the work of Erdtman (1960), Barth and Melhem (1988), and Punt et al. (2007). The polar (DP) and equatorial (DE) diameters of the pollen grains were measured with Hund H-500 Wetzlar (Helmut Hund Gmbh, German) optical microscope, in 100x immersion objective, with lucid camera Leitz Wetzlar opto-coupler.

Parts of the plants of these botanical species containing leaves and flowers were also removed for mounting herbarium specimens, which were deposited in the Herbarium of the National Museum/UFRJ, under the following registration numbers: R-212.562, R-212.563 and R-212.564 for A. graveolens, C. sativum, and F. vulgare, respectively.

\subsection{Evaluation of the capacity of pollen ingestion}

The experiment was mounted with a $3 \times 2 \times 2$ factorial structure, with three Apiaceae species [coriander $\left(\mathrm{S}_{0}\right)$, dill $\left(\mathrm{S}_{1}\right)$ and fennel $\left(\mathrm{S}_{2}\right)$ ], two life phases of the insect [fourth instar larval $\left(\mathrm{LP}_{0}\right)$ and adult $\left.\left(\mathrm{LP}_{1}\right)\right]$ and the time of exposure of the flowers [24 hours $\left(\mathrm{T}_{0}\right)$ and 48 hours $\left(\mathrm{T}_{1}\right)$ ], in five repetitions, conducted in climate-controlled conditions of temperature $\left(25 \pm 1{ }^{\circ} \mathrm{C}\right)$, of relative humidity $(70 \pm 10 \%)$ and photophase of 12 hours in an acclimatized room of the Centro Integrado de Manejo de Pragas (CIMP) at the UFRRJ, from August of 2011 to May of 2012.

The C. maculata individuals used in the experiment were obtained from laboratory mass rearing established at the CIMP, since 2008. Sporadically, new C. maculata adults were inserted to the rearing, aiming to prevent the occurrence of endogamy and the loss of vigor. The adults were kept in transparent disposable plastic pots, capacity 1 liter, in a climate-controlled room $\left(25 \pm 1^{\circ} \mathrm{C}, 70 \pm 10 \%\right.$ $\mathrm{RH}$ and photophase of 12 hours). An average of five adults per pot was established, with at least one couple present. The pots were closed with organza screen lids to allow the gas exchange. Initially these adults were fed on ad libitum UV-irradiated eggs of Anagasta kuehniella (Zeller, 1879) (Lepidoptera: Pyralidae) (artificial prey), supplied by Insecta Agentes Biológicos (Lavras, MG), and water, that provided by a ball of absorbent cotton moistened with filtered water and placed in PET plastic bottle caps.

The newly-opened flowers were collected from flowerbeds and gathered in a bouquet, where each one was immediately placed in a $20 \mathrm{~mL}$ glass vial containing water, and secured to the top of the vial with cotton. Four flower bouquets of the same species were placed inside polyethylene and fine mesh $\left(1 \mathrm{~mm}^{2}\right)$ cages $\left(\right.$ Bioquip $\left.^{\circledR}\right)$, measuring $30 \mathrm{~cm} \times 30 \mathrm{~cm} \times 30 \mathrm{~cm}$, with one bouquet in each corner of the cage. Next, five $C$. maculata individuals per cage were released, prior to which fasting for 24 hours, to increase the chances for ingestion of the pollen grains. In total, 150 fourth instar larvae and 150 adults (approximately 30 days old) of C. maculata were used. Thus, larvae and adults were randomly divided into three groups of
50 individuals, one group for each botanical species, with no chance of choosing. Each group of 50 was divided into two equal subgroups, where the variable was the amount of time the insect was exposed to the flowers: 25 remained for 24 hours in contact with the flowers, while the other 25 remained for 48 hours; therefore, there were 5 cages for each treatment. In this way, each cage constituted an experimental plot, in working with the mean number of adults and larvae of lady beetles of each cage.

At the end of each exposure time, the lady beetles were frozen to death; the next day the legs and wings were removed (in the case of adults) to reduce the amount of residue after the insects underwent acetolysis, which was conducted in the same place where the floral buds also underwent acetolysis procedure, using the same method.

Prior to acetolysis, the mutilated insects were washed with distilled water to eliminate any pollen grains that could be present on the external part of the body, so as not to overestimate the results. Afterwards, each insect was placed in a $1.5 \mathrm{~mL}$ micro-test Eppendorf tube and labeled with vegetable paper. Following this, each insect was transferred to a test tube to undergo acetolysis for the destruction of tissue and other organic parts, but with the preservation of the possibly ingested pollen grains, which would be retained in the decanted material at the bottom of the test tube. Then, to quantify the pollen grains possibly ingested by the insects, microscopic slides were prepared, using the same methodology used for the floral buds.

It was observed that some presuppositions of variance analysis had not been met, making it necessary to fall back on data transformation. The value used in the transformation was suggested by the procedure of Box and Cox (1964). Then the data underwent variance analysis and for mean comparison the Tukey test at $5 \%$ probability was used, using the R statistical software, version 2.15.0 (R Development Core Team, 2012). In relation to the dependence of the factors analyzed in the present study, by variance analysis, it was verified by the $\mathrm{F}$ test that the interaction among the evaluated plant species $(\mathrm{S}) \times$ time of exposure $(\mathrm{T}) \times$ life phase (LP) of the insect was significant $(\mathrm{p}<0.01)$, indicating the existence of dependence between the effects of these factors. Thus, to improve data interpretation, the unfolding of interaction was necessary to conduct. It was carried out the unfolding of interaction of Apiaceae species (S) within the combination C. maculata life phases (LP) and time of exposure to the flowers of these species (T), the unfolding of interaction of C. maculata life phases (LP) within the combination Apiaceae species (S) and time of exposure to the flowers of these species (T), and the unfolding of interaction of time of exposure to the flowers of these species (T) within the combination Apiaceae species (S) and C. maculata life phases (LP).

\section{Results and Discussion}

\subsection{Pollen morphology}

It wasn't possible to morphologically differentiate the pollen grains of all three Apiaceae species, as the form, ornamentation, as well as the dimensions of the aperture were 
all similar (see Figure 1), being monads, isopolar, medium $(32.5 \times 12.5 \mu \mathrm{m})$, perprolate $(\mathrm{DP} / \mathrm{DE}=2.6) \mathrm{amb}$ triangular, tricolporate, long colpi and endoaperture lalongate, lalo with microreticulate ornamentation. Some of these characteristics are cited by Jones and Jones (2001) for Apiaceae pollen grains. Therefore, the morphological similarity between the pollen grains prevented the simultaneous offer of their flowers, and thus, these were offered individually to the fourth instar larvae and C. maculata adults, in order to detect possible differences in the quantity of pollen grains consumed by them, among the aromatic flowers.

\subsection{Ingestion of pollens by C. maculata}

Pollen grains of the three Apiaceae species were recovered from both life phases of $C$. maculata, where at least one individual from each repetition/cage ingested the grain. This result corroborates those of Smith (1965) and Lundgren et al. (2005), who observed that larvae of C. maculata also ingest pollen grains, not only the adults. This result also indicates that this lady beetle species accepted the pollen grains of the three species as food, however, more studies are needed to conclude if this food is adequate to guarantee its survival and reproduction, preferentially leading to longer lifespan of adults and fecundity, or whether it is simply a complementary food source that would only warrant its survival, as was pointed out by Almeida and Ribeiro-Costa (2009).

Taking all the evaluations into consideration, $22.3 \%$, $26.3 \%$ and $51.4 \%$ of the total sum of pollen grains that were recovered $(n=69679)$ were of coriander, fennel and dill, respectively (as shown in Table 1). The numbers obtained in this study showed to be higher than those found by Medeiros et al. (2010) for H. convergens, from which they recovered 46 pollen grains from 43 adults, being six pollen grains of Apiaceae, but without identifying the botanical species; however, most of the pollen grains found in the digestive tract of this lady beetle belonged to Asteraceae (16 grains of Aspilia Thou.). Nevertheless, the individuals analyzed by these authors were gathered in field, and one of the characteristics of coccinellids is polyphagia, therefore the pollen grains are alternative and/ or complementary food (Hoffmann and Fordsham, 1993; Iperti, 1999; Almeida and Ribeiro-Costa, 2009). Furthermore,
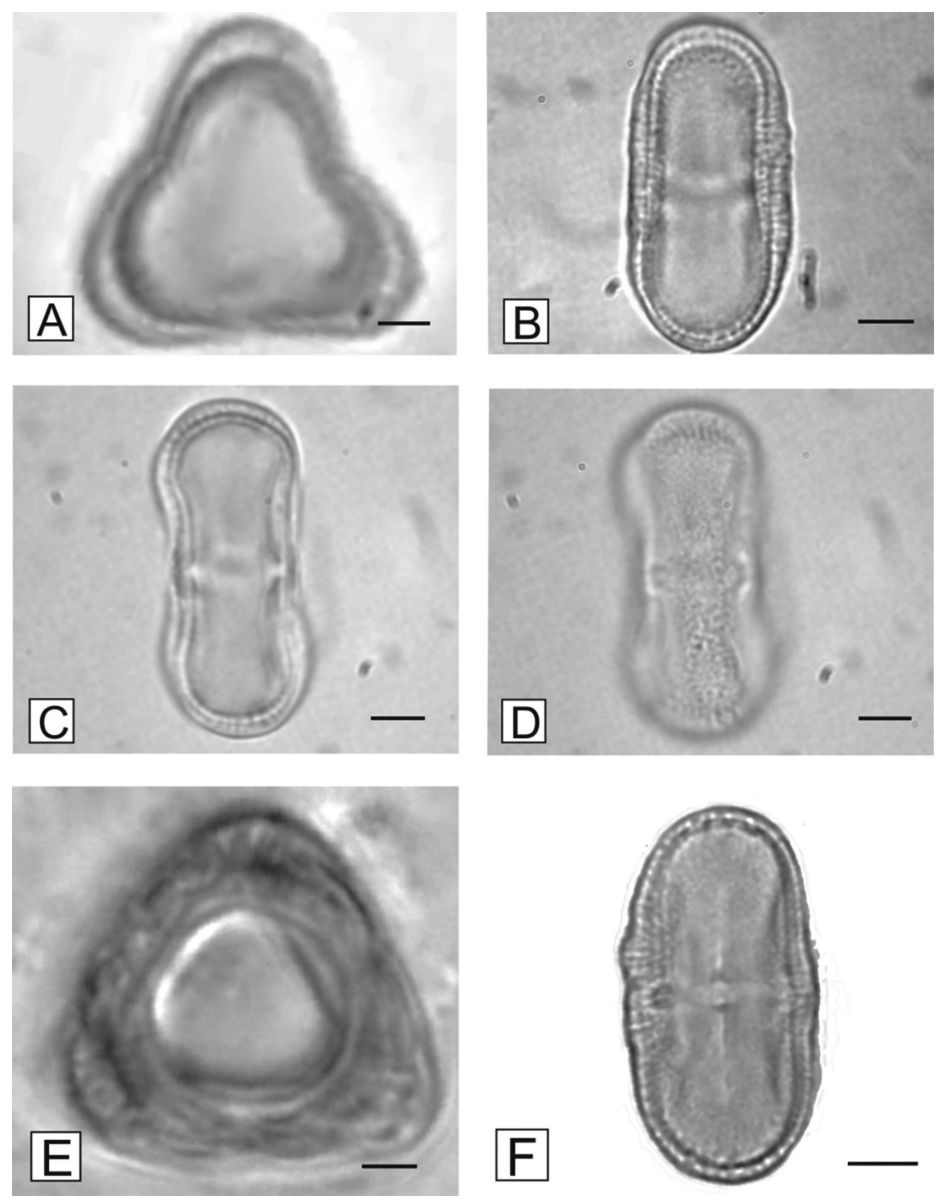

Figure 1. Photomicrograph of Apiaceae pollen grains. Polar view (A) and equatorial view (B) of fennel pollen grain (Foeniculum vulgare Mill.); equatorial view (C) and surface (D) of coriander pollen grain (Coriandrum sativum L.); polar view (E) and equatorial view (F) of dill pollen grain (Anethum graveolens L.). Scale $5 \mu \mathrm{m}$. 
Table 1. Total number of pollen grains of the three Apiaceae species recovered in adults and fourth instar larvae of Coleomegilla maculate, in two exposure times to the flowers of these species in laboratory conditions $\left(25 \pm 1{ }^{\circ} \mathrm{C}, 70 \pm 10 \%\right.$ RH and photophase of 12 hours).

\begin{tabular}{|c|c|c|c|c|c|}
\hline \multirow{2}{*}{ Botanical species } & \multicolumn{2}{|c|}{ Adult } & \multicolumn{2}{|c|}{$4^{\text {th }}$ instar larvae } & \multirow{2}{*}{ Total } \\
\hline & $24 \mathrm{~h}$ & $48 \mathrm{~h}$ & $24 \mathrm{~h}$ & $48 \mathrm{~h}$ & \\
\hline Coriander (Coriandrum sativum) & 1062 & 4160 & 2328 & 8016 & 15566 \\
\hline Dill (Anethum graveolens) & 25823 & 1014 & 3134 & 5807 & 35778 \\
\hline Fennel (Foeniculum vulgare) & 22 & 3826 & 4430 & 10057 & 18335 \\
\hline
\end{tabular}

another important consideration is that certain species of Hippodamia only present normal oogenesis when they feed upon their favorite prey (aphids), stimulating oviposition (Hagen, 1987; Iperti, 1999). These facts may explain, at least in part, the recovery of a greater number of pollen grains in the present study, carried out in conditions of laboratory confinement.

There are few studies regarding the quantification in numerical terms of pollen grains ingested by predator lady beetles. In some studies on C. maculata, the results are presented in terms of weight, which renders further comparative discussions difficult. However, Lundgren et al. (2005) estimated that the consumption of corn pollen grains (Z. mays) by fourth instar larvae of C. maculata was of $3.30 \mathrm{mg}$ and the adults consumed $13.15 \mathrm{mg}$ of pollen of this Poaceae during the period of anthesis in transgenic corn crops in Illinois, USA, without mentioning what this represents in terms of the number of ingested pollen grains. Dupuis et al. (1987) estimated that 2500 Z. mays pollen grains in one milligram, therefore, considering only the consumption of fourth instar larvae and of adults of C. maculata recorded by Lundgren et al. (2005), would give a total of 41125 pollen grains. Therefore, it gives a quantity relatively higher than the consumption of Apiaceae grains by these phases in the present study, reaching a peak of $14.94 \%$ greater than the dill grains. Although it is not possible to affirm, the lower ingestion of Apiaceae pollens might be due to the higher protein content. Roulston et al. (2000) recorded that the protein content of the $Z$. mays pollen is $23.9 \%$, and $29.0 \%$ for the Anthriscus sylvestris (L.) (Apiacae). Nevertheless, data in the literature as to the protein content of Apiaceae pollens evaluated in the present study were not found. Furthermore, according to Patt et al. (1997a), the morphology of dill and coriander flowers, that present exposed stamens above the petals, is compatible with the morphology of the head of the C. maculata, facilitating prompt access to the pollen, as well as the floral nectar.

The result of the unfolding of the interaction between the factors can be seen in Table 2. Comparing the three botanical species among themselves, in 24 hours of exposure to the flowers, the quantity of pollen grains from the three species ingested by the fourth instar larvae of $C$. maculata was significantly the same. On the other hand, the adults of this lady beetle ingested significantly more pollen grains of dill than grains of the other two Apiaceae. However, there was no significant difference in the ingestion of pollen of these aromatic plants for the life
Table 2. Mean number of pollen grains of the three Apiaceae species ingested during the adult and larval phases of Coleomegilla maculata in two exposure times to the flowers in laboratory conditions $\left(25 \pm 1{ }^{\circ} \mathrm{C}, 70 \pm 10 \% \mathrm{RH}\right.$ and photophase of 12 hours).

\begin{tabular}{|c|c|c|c|c|}
\hline & \multirow{2}{*}{ Phase } & \multicolumn{3}{|c|}{ Botanical species } \\
\hline & & Dill & Fennel & Coriander \\
\hline \multirow{5}{*}{ 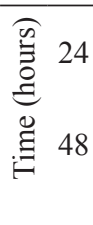 } & Larvae & $125.36 \mathrm{bA}$ & $177.20 \mathrm{aA}$ & $93.12 \mathrm{aA}$ \\
\hline & Adult & $1032.92 \mathrm{aA}$ & $0.88 \mathrm{bB}$ & $18 \mathrm{bB}$ \\
\hline & Larvae & $232.28 \mathrm{bA}$ & $402.28 \mathrm{aA}$ & $320.64 \mathrm{aA}$ \\
\hline & Adult & $75.16 \mathrm{bA}$ & $153.04 \mathrm{aA}$ & $164.45 \mathrm{aA}$ \\
\hline & CV $(\%)$ & & 21.91 & \\
\hline
\end{tabular}

Means followed by the same lower case letter in the columns or same capital letter in the lines do not differ statistically among themselves by the Tukey test at $5 \%$ of probability.

phases of C. maculata, in 48 hours of exposure. The greater consumption of dill pollen grains might be explained by the food quality, although this was not evaluated in the present study. Nonetheless, food of low nutritional quality may be ingested in larger quantities in comparison to that of high quality, to compensate for the nutritional demands (Almeida and Ribeiro-Costa, 2009).

Then the preference of the adults for dill pollen, as a result of the larger number of pollen grains recovered in the first 24 hours, might be the result of the adults' greater acceptance of dill pollen as food. But it is still necessary to conduct bromatological analyses of the pollen grains and complementary experiments to evaluate the suitability of the pollen as "essential" food for C. maculata, that is, which would allow its complete development, or as "alternative" food, which only prolongs its survival, as pointed out by various authors (Smith, 1965; Iperti and Trepanier-Blais, 1972; Almeida and Ribeiro-Costa, 2009).

However, according to Patt et al. (1997a, b), both adults and larvae of $C$. maculata forage for dill pollen and nectar because its plants have exposed stamens and nectaries in umbel-type flowers, granting easy access to these individuals, while the flowers of coriander plants, despite being of the same type, have partially hidden nectaries by other parts of the flowers, possibly making them less attractive to $C$. maculata adults.

Regarding pollen ingestion between $C$. maculata adults and larvae (as shown in Table 2) for the same botanical species, in the first 24 hours, the adults ingested almost 8.24 times more dill pollen grains than the larvae. 
The opposite occurred when these individuals were offered fennel flowers, where the larvae ingested, on average, 200 times more pollen grains than that ingested by the adults. The difference in the amount of ingested dill pollen grains between larvae and adults of $C$. maculata might be due to the fact that the females have a greater nutritional demand for this pollen in order to carry out oviposition, seeing as this lady beetle species is able to mature its eggs by consuming a pollen diet alone (Almeida and Ribeiro-Costa, 2009), which also happens with other predator insects such as females of Melangyna novaezelandiae (Macquart, 1855) (Diptera: Syrphidae) (Wratten et al., 1995; Irvin et al., 1999). In the 48-hour period, there was no significant difference in the amount of ingested pollen grains of each Apiaceae species between adults and larvae of $C$. maculata (as shown in Table 2).

It is possible to note further that, compared to the other treatments, the amount of fennel pollen grains ingested by C. maculata adults, as well as the larvae, was the smallest observed in the 24-hour period, whereas the amount of ingested pollen grains did not differ significantly from those of coriander. Some authors cite that flowers of fennel have exposed floral nectaries (Patt et al., 1997a, b), which might indicate a deviation of the insects' attention to obtain nectar instead of pollen, depending on the physiological condition and nutritional demands of the confined individuals. Thus, one would assume that C. maculata adults would at first prefer to feed on the floral nectar of fennel, and consequently, would ingest a lesser amount of pollen grains of this species. However, due to the difficulty of identifying gender of coccinellids (Gordon, 1978), it was impossible to ascertain the sexual reason before offering the Apiaceae flowers, hence, this difference between the amount of ingested pollen between genders rendered it impossible to carry out statistical tests. Furthermore, as pointed out previously, the similarity among the external morphology of the pollens of the three Apiaceae did not allow the simultaneous offer to test a possible preference. It is thus advised, for future studies, to invest in a methodology that enables to make a sexual differentiation so as to offer the flowers separately to males and females.

As to the coriander, larvae and adults ingested the same amount of pollen grains. Most likely, the fact that coriander flowers present shallow corolla (Vattala et al., 2006) facilitated full access for these individuals to the pollen grains, explaining at least in part why the two life phases had equal opportunity to ingest the same amount of pollen.

Comparing both times of exposure to the flowers (as shown in Table 2), the results showed no significant difference in the ingestion of pollen grains by fourth instar larvae of C. maculata among the three Apiceae species, in contrast to the adults. The consumption of dill pollen grains by adults of this lady beetle was significantly higher in 24 hours than in 48 hours, with the opposite occurring with the consumption of fennel and coriander pollen grains. These results suggest that, in the absence of another food source, C. maculata adults tend to continue and increase the ingestion of coriander and fennel pollen grains. In a sense, at first we might have thought that rejection occurred after some time, due to unsuitability or delayed toxicity of dill pollen grains as a food source for adults, but it seems that the more probable hypothesis is that $C$. maculata adults that were confined for 48 hours consumed such a high amount of dill pollen that there were not as many grains to be consumed in the next 24 hours, which might also explain why the consumption of dill pollen grains being offered for 48 hours did not repeat the high averages.

Although different species of biological control agents have varying nutritional needs, the evidence showing that an important predator ingests pollen of three plant species is a big breakthrough that supports further research in the selection of attractive plants for natural enemies in order to form the agricultural system designs and contribute toward the practical application of conservative biological control in agro-ecosystems in Brazil, similar to what already occurs in other countries (Ambrosino et al., 2006; Ambrosino, 2014).

\section{Acknowledgements}

We thank Coordenação de Aperfeiçoamento de Pessoal de Nível Superior (CAPES) for the magister science scholarship to the first author. This study was supported by the Fundação de Apoio a Amparo à Pesquisa do Estado do Rio de Janeiro (FAPERJ) (Process E-26/110.287/2010).

\section{References}

ALMEIDA, L.M. and RIBEIRO-COSTA, C.S., 2009. Coleópteros predadores (Coccinellidae). In: A.R. PANIZZI and J.R.P. PARRA, eds. Bioecologia e nutrição de insetos: base para o manejo integrado de pragas. Brasília: Embrapa Informação Tecnológica, pp. 931-968.

AMBrosinO, M., 2014 [viewed 3 March 2015]. Practical guidelines for establishing, maintaining and assessing the usefulness of insectary plantings on your farm [online]. Oregon: Integrated Plant Protection Center, Oregon State University. Available from: http://www.ipmnet.org/Posters_and_Presentations/ Farm_Insectary_Plant_Manual_Draft2_Pressqual1.pdf

AMBROSINO, M.D., LUNA, J.M., JEPSON, P.C. and WRATTEN, S.D., 2006. Relative frequencies of visits to selected insectary plants by predatory hoverflies (Diptera: Syrphidae), other beneficial insects and herbivores. Environmental Entomology, vol. 35, no. 2, pp. 394-400. http://dx.doi.org/10.1603/0046-225X-35.2.394.

BARBOSA, F.S., AGUIAR-MENEZES, E.L., ARRUDA, L.N., SANTOS, C.L.R. and PEREIRA, M.B., 2011. Potencial das flores na otimização do controle biológico de pragas para uma agricultura sustentável. Revista Brasileira de Agroecologia, vol. 6, no. 2, pp. 101-110.

BARTH, O.M. and MELHEM, T.S., 1988. Glossário ilustrado de palinologia. Campinas: UNICAMP. $75 \mathrm{p}$.

BOX, G E.P. and COX, D.R., 1964. An analysis of transformations. Journal of the Royal Statistical Society. Series B, Statistical Methodology, vol. 26, no. 2, pp. 211-252. 
CLERCQ, P., BONTE, M., VAN SPEYBROECK, K., BOLCKMANS, K. and DEFORCE, K., 2005. Development and reproduction of Adalia bipunctata (Coleoptera: Coccinellidae) on eggs of Ephestia kuehniella (Lepidoptera: Phycitidae) and pollen. Pest Management Science, vol. 61, no. 11, pp. 1129-1132. http://dx.doi.org/10.1002/ ps.1111. PMid:16144016

DUPUIS, I., ROECKEL, P., MATTHYS-ROCHON, E. and DUMAS, C., 1987. Procedure to isolate viable sperm cells from corn (Zea mays L.) pollen grains. Plant Physiology, vol. 85, no. 4, pp. 876-878. http://dx.doi.org/10.1104/pp.85.4.876. PMid:16665823.

ERDTMAN, G., 1960. Pollen morphology and plant taxonomy: angiosperms. New York: Almqvist and Wiksell. 553 p.

GORDON, R.D., 1978. West Indian Coccinellidae II (Coleoptera): some scale predators with key to genera and species. Coleopterists Bulletin, vol. 32, no. 3, pp. 205-218.

HAGEN, K.S., 1987. Nutritional ecology of terrestrial insect predators. In: F. SLANSKY and J.G. RODRIQUEZ, eds. Nutritional ecology of insects, mites, spider and related invertebrates. New York: John Wiley, pp. 533-577.

HARMON, J.P., IVES, A.R., LOSEY, J.E., OLSON, A.C. and RAUWALD, K.S., 2000. Coleomegilla maculata (Coleoptera: Coccinellidae) predation on pea aphids promoted by proximity to dandelions. Oecologia, vol. 125, no. 4, pp. 543-548. http:// dx.doi.org/10.1007/s004420000476.

HODEK, I. and HONEK, A.,1996. Ecology of Coccinellidae. London: Kluwer Academic. 464 p. http://dx.doi.org/10.1007/97894-017-1349-8.

HOFFMANN, M.P. and FORDSHAM, A.C.,1993. Natural enemies of vegetable insect pests. Ythaca: Cornell Cooperative Extension, Cornell University. $63 \mathrm{p}$.

IPERTI, G. and TREPANIER-BLAIS, N., 1972. Valeur alimentaire des œufs d'Anagasta kuehniella Z. [Lepid.: Pyralidae] pour une coccinelle aphidiphage:Adonia 11-notata Schn. [Col. Coccinellidae]. Entomophaga, vol. 17, no. 4, pp. 437-441. http:// dx.doi.org/10.1007/BF02371649.

IPERTI, G., 1999. Biodiversity of predaceous Coccinellidae in relation to bioindication and economic importance. Agriculture, Ecosystems \& Environment, vol. 74, no. 1-3, pp. 323-342. http:// dx.doi.org/10.1016/S0167-8809(99)00041-9.

IRVIN, N.A., WRATTEN, S.D., FRAMPTON, C.M., BOWIE, M.H., EVANS, A.M. and MOAR, N.T., 1999. The phenology and pollen feeding of three hover fly (Diptera: Syrphidae) species in Caterbury, New Zealand. New Zealand Journal of Zoology, vol. 26, no. 2, pp. 105-115. http://dx.doi.org/10.1080/0301422 3.1999.9518182.

JONES, G.D. and JONES, S.D., 2001. The uses of pollen and its implication for entomology. Neotropical Entomology, vol. 30, no. 3, pp. 341-350. http://dx.doi.org/10.1590/S1519-566X2001000300001.

KISSER, J., 1935. Bemerkungen Zum Einschluss in glyceringelatine. Zeitschrift fur Wissenschaftliche Mikroskopie und Mikroskopische Technik, vol. 51, pp. 372-374.

LIXA, A.T., CAMPOS, J.M., RESENDE, A.L., SILVA, J.C., ALMEIDA, M.M. and AGUIAR-MENEZES, E.L., 2010. Diversidade de Coccinellidae (Coleoptera) em plantas aromáticas (Apiaceae) como sítios de sobrevivência e reprodução em sistema agroecológico. Neotropical Entomology, vol. 39, no. 3, pp. 354359. http://dx.doi.org/10.1590/S1519-566X2010000300007. PMid:20676507.
LUNDGREN, J.G., HUBER, A. and WIEDENMANN, R.N., 2005. Quantification of consumption of corn pollen by the predator Coleomegilla maculata (Coleoptera: Coccinellidae) during antesis in an Illinois cornfield. Agricultural and Forest Entomology, vol. 7, no. 1, pp. 53-60. http://dx.doi.org/10.1111/ j.1461-9555.2005.00246.x

MEDEIROS, M.A., RIBEIRO, P.A., MORAIS, H.C., CASTELO BRANCO, M., SUJII, E.R. and SALGADO-LABORIAU, M.L., 2010. Identification of plant families associated with the predators Chrysoperla externa (Hagen) (Neuroptera: Chrysopidae) and Hippodamia convergens Guérin-Menéville (Coleoptera: Coccinelidae) using pollen grain as a natural marker. Brazilian Journal of Biology $=$ Revista Brasileira de Biologia, vol. 70, no. 2, pp. 293-300. http://dx.doi.org/10.1590/S1519-69842010005000011.

MELHEM, T.S., CRUZ-BARROS, M.A.V., CORRÊA, M.A.S. and MAKINO-WATANABE, H., SILVESTRE-CAPELATO, M.S.F. and GONÇALVES-ESTEVES, V.L., 2003. Morfologia polínica em plantas de Campos do Jordão (São Paulo, Brasil). São Paulo: Instituto de Botânica. 104 p. Boletim do Instituto de Botânica de São Paulo.

OBRYCKI, J.J. and KRING, J.T., 1998. Predaceous coccinellidae in biological control. Annual Review of Entomology, vol. 43, no. 1, pp. 295-321. http://dx.doi.org/10.1146/annurev.ento.43.1.295. PMid:15012392.

PATT, J.M., HAMILTON, G.C. and LASHOMB, J., 1997a. Impact of strip insectary intercropping with flowers on conservation biological control of the Colorado potato beetle. Advances in Horticultural Science, vol. 11, no. 4, pp. 175-181

PATT, J.M., HAMILTON, G.C. and LASHOMB, J.H., 1997 b. Foraging success of parasitoid wasps on flowers: interplay of insect morphology, floral architecture and searching behavior. Entomologia Experimentalis et Applicata, vol. 83, no. 1, pp. 21-30. http://dx.doi.org/10.1046/j.1570-7458.1997.00153.x.

PUNT, W., HOEN, P.P., BLACKMORE, S., NILSSON, S. and LE THOMAS, A., 2007. Glossary of pollen and spore terminology. Review of Palaeobotany and Palynology, vol. 143, no. 1-2, pp. 1-81. http://dx.doi.org/10.1016/j.revpalbo.2006.06.008.

R DEVELOPMENT CORE TEAM, 2012 [viewed 5 July 2012]. $R$ : a language and environment for statistical computing [online]. Vienna: R Foundation for Statistical Computing. Available from: http://www.R-project.org

RESENDE, A.L.S., LIXA, A.T., SANTOS, C.M.A., SOUZA, S.A.S., GUERRA, J.G.M. and AGUIAR-MENEZES, E.L., 2011. Comunidade de joaninhas (Coleoptera: Coccinellidae) em consórcio de couve (Brassica oleraceae var. acephala) com coentro (Coriandrum sativum) sob manejo orgânico. Revista Brasileira de Agroecologia, vol. 6, no. 1, pp. 81-89.

ROULSTON, T.H., CANE, J.H.C. and BUCHMANN, S.L., 2000. What governs protein content of pollen: pollinator preferences, pollen-pistil interactions, or phylogeny? Ecological Monographs, vol. 70 , no. 4 , pp. $617-643$

SMITH, B.C., 1965. Differences in Anatis mali Auct. and Coleomegilla maculata lengi Timberlake to changes in the quality and quantity of the larval food (Coleoptera: Coccinellidae). Canadian Entomologist, vol. 97, no. 11, pp. 1159-1166. http:// dx.doi.org/10.4039/Ent971159-11.

VATTALA, H.D., WRATTEN, S.D., PHILLIPS, C.B. and WACKERS, F.L., 2006. The influence of flower morphology and 
nectar quality on the longevity of a parasitoid biological control agent. Biological Control, vol. 39, no. 2, pp. 179-185. http:// dx.doi.org/10.1016/j.biocontrol.2006.06.003.

WEBER, D.C. and LUNDGREN, J.G., 2011. Effect of prior diet on consumption and digestion of prey and non-prey food by adults of the generalist predator Coleomegilla maculata. Entomologia
Experimentalis et Applicata, vol. 140, no. 2, pp. 146-152. http:// dx.doi.org/10.1111/j.1570-7458.2011.01141.x.

WRATTEN, S.D., WHITE, A.J., BOWIE, M.H., BERRY, N.A. and WEIGMANN, U., 1995. Phenology and ecology of hoverflies (Diptera: Syrphidae) in New Zealand. Environmental Entomology, vol. 24, no. 3, pp. 595-600. http://dx.doi.org/10.1093/ee/24.3.595. 